\title{
Effect of the Quail Phenotype and Breeding Age on Egg Laying and Characteristics
}

\author{
Djitie Kouatcho François ${ }^{1 *}$, Alvine Eleonor Akana2, Razvan Mihail Radu-Rusu ${ }^{3}$, \\ Alina Teodorescu ${ }^{3}$, Marius Giorgi Usturoi ${ }^{3}$, Ferdinand Ngoula ${ }^{4}$, Alexis Teguia ${ }^{4}$ \\ ${ }^{1}$ Department of Biological Sciences, Faculty of Sciences, University of Ngaoundéré, Ngaoundéré, Cameroon \\ ${ }^{2}$ Department of Life Sciences, HTTS Bertoua University of Ngaoundéré, Ngaoundéré, Cameroon \\ ${ }^{3}$ Department of Animal Production Management, Animal Science Faculty, UASVM Iasi, Iasi, Romania \\ ${ }^{4}$ Department of Animal Science, FASA, University of Dschang Cameroon, Dschang, Cameroon \\ Email: *franckdjitie@gmail.com
}

How to cite this paper: Djitie, K.F., Akana, A.E., Radu-Rusu, R.M., Teodorescu, A., Usturoi, M.G., Ngoula, F. and Teguia, A. (2021) Effect of the Quail Phenotype and Breeding Age on Egg Laying and Characteristics. Open Journal of Animal Sciences, $11,208-221$.

https://doi.org/10.4236/ojas.2021.112016

Received: January 4, 2021

Accepted: April 12, 2021

Published: April 15, 2021

Copyright $\odot 2021$ by author(s) and Scientific Research Publishing Inc. This work is licensed under the Creative Commons Attribution International License (CC BY 4.0).

http://creativecommons.org/licenses/by/4.0/

\begin{abstract}
In order to evaluate the effect of phenotype and quail age on laying rate and egg characteristics, a study has been carried out in Ngaoundéré from February to August 2019. 216 quails were divided into 36 batches of 6 animals each (5 females and 1 male) according to age and phenotype. The experimental animals were white, spotted white, grey and brown phenotypes and were one, six and ten months old. Eggs were collected for three weeks between $8 \mathrm{pm}-4$ pm and $4 \mathrm{pm}-8 \mathrm{pm}$, counted, weighed and measured. 15 eggs per phenotype were randomly selected, broken individually, which allowed the internal parameters to be evaluated. The main results show that the quails laid more eggs between $4 \mathrm{pm}-8 \mathrm{pm}$, the highest laying rate was obtained in quails at one moth of laying and the spotted white phenotype had a high laying rate $(74.03 \%)$ compared to other phenotypes. At one month of breeding age, quails with the spotted white phenotype showed a higher laying rate (93.34\%), brown (78.75\%) and grey (74\%) at six months and finally white (71\%) at ten months. Weight, height, diameter and egg shape index did not vary with the quail phenotype. The highest egg volume $(12.60 \mathrm{ml})$ was found in white quails. The shells of white spotted quails were thicker than those of other phenotypes. Grey quails laid eggs with the highest Haugh's index and proportion of edible matter. Brown quail eggs were found to have a higher proportion of dry yolk matter. Dry matter and moisture content of albumen did not vary with the quail phenotype. Considering the results obtained, it has been concluded that spotted white phenotype quails are more suitable for reproduction as they presented the best egg-laying proportions of edible matter.
\end{abstract}




\section{Keywords}

Oviposition, Eggs, Plumage Colour, Quail, Sudano-Guinean Zone

\section{Introduction}

Poultry farming has mainly focused on the production of chicken eggs and broiler chickens. In 2012, the poultry sector supplied 103 million tons of meat and 66.4 million tons of eggs for consumption worldwide [1]. According to FAO estimates, the food needs of the world's population will increase by $70 \%$ by 2050 [2]. Short-cycle animal husbandry, such as quail farming, can be an important asset in meeting animal protein requirements and reducing pressure on chicken and hen egg production. Improvements in quail rearing have been undertaken in order to take advantage of their characteristics, notably the early age of the bird in meat production (5 weeks), its laying performance (200 - 300 eggs per year) and its relatively short generation interval compared to other avian species [3]. Quail is reared for its meat and eggs, for its therapeutic virtues, taste and high nutritional value [4] [5]. The need of eggs for consumption is increasing and consumers are looking at the quality of poultry products. Thus, depending on the objectives, each farm has developed a strain with its own characteristics, which explains the great heterogeneity of populations and zootechnical [6]. On the whole, studies have been carried out on growth performance, egg laying and egg quality [7] [8], as well as the effect of genotype on the characteristics of Japanese quail eggs [9]. In Cameroon studies have been carried out on the effect of crude protein level on growth and carcass in quail (Coturnix sp.) in the finishing phase in the Cameroonian highlands [4], also on the characteristics of quail breeding [10]. However, no research has been focused on egg-laying performance as a function of age and phenotype of quail, hence the need for this study in the Sudano-Guinean zone of Cameroon. The general objective of this study is to contribute to the better management of quail reproduction by knowing the appropriate phenotype and age for better reproduction and quality of quail eggs in order to meet the food needs of populations.

Specifically, the effect on quails will be evaluated on the laying rate and egg characteristics.

\section{Materials and Methods}

\subsection{Study Area}

This study was carried out in the city of Ngaoundéré, Adamaoua Region of Cameroon. It is located between the 6th and 8th degrees of latitude North and between the 11th and 15th degrees of longitude East. The average annual temperature varies from $23^{\circ} \mathrm{C}$ to $25^{\circ} \mathrm{C}$ and the annual rainfall varies between 900 and $1500 \mathrm{~mm}$. 


\subsection{Animal Material, Housing and Feeding}

A stock of 216 quails of 4 phenotypes (white, spotted white, grey and brown) each with animals of three breeding age groups (1, 6 and 10 months of laying) was used in this study. Birds were housed in cages made of plank and wire mesh of small mesh, given the small size of the birds. They were fed with a diet having a centesimal composition as shown in Table 1 below.

\subsection{Experimental Design and Trial Management}

216 quails of three laying age (one, six and ten months) were divided into 36 flocks of 6 animals each ( 5 females and 1 male) according to phenotype (white, spotted white, grey and brown) and breeding age. For each laying age and per phenotype, we had 18 quails ( 15 females and 3 males) for a total of 72 quails per age class for the 4 phenotypes. Water and food were served ad libitum throughout the trial. In all cages, birds were kept under the same conditions.

\subsection{Data Collection and Studied Parameters}

Egg-laying was monitored over 21 days and during this trial period, the following parameters were evaluated according to phenotype and age.

Table 1. Percent composition of the layer diet.

\begin{tabular}{|c|c|}
\hline Ingredients & Quantity (kg) \\
\hline Corn & 60 \\
\hline Soya cake & 16 \\
\hline Wheat bran & 5 \\
\hline Fish meal & 7 \\
\hline Bone meal & 0,5 \\
\hline Shellfish powder & 0,5 \\
\hline Laying concentrate $5 \%$. & 5 \\
\hline Peanut cake & 5 \\
\hline Palm oil & 1 \\
\hline Total & 100 \\
\hline \multicolumn{2}{|l|}{ Chemical characteristics (\%MS) } \\
\hline Protein content $(\%)$ & 22 \\
\hline Metabolizable Energy (kcal/kg) & 3000 \\
\hline Fat (\%) & 4.47 \\
\hline Calcium (\%) & 1.23 \\
\hline Phosphorus (\%) & 0.64 \\
\hline Lysine (\%) & 1.32 \\
\hline Methionine (\%) & 1.48 \\
\hline
\end{tabular}




\subsubsection{Periodicity and Laying Rate}

Eggs collected every day at regular times (4 pm and $8 \mathrm{pm}$ ) according to phenotype and age, were counted, weighed and measured. Based on the number of eggs collected, the weekly laying rate for each phenotype and age was calculated using the formula below.

$$
\text { Laying rate }=[(\text { Number of eggs laid }) /(\text { Number of females } \times 7)] \times 100
$$

\subsubsection{External and Internal Characteristics of the Eggs}

Eggs of each time slot according to phenotype and age were individually weighed using an electronic scale with a $300 \mathrm{~g}$ capacity and $0.01 \mathrm{~g}$ accuracy. Large diameter and height were measured using a digital caliper with a range of $150 \mathrm{~mm}$ and accuracy of $0.01 \mathrm{~mm}$. These two parameters were evaluated: Shape index using the ratio between the large diameter and the height of the egg multiplied by 100 . Volume of egg was estimated by inserting the egg into a graduated cylinder containing a known volume of water. Egg volume (Vo) was determined as the difference between the volume after introduction of the egg ( Vf) and the initial volume (Vi). At the end of the trial, 30 eggs per phenotype were randomly selected, broken individually and their contents gently spread out on a glass plate on a flat surface. Yolk and albumen height, yolk and white diameter as well as the thickness of dense albumen were measured using the digital caliper. After the measurements, yolk was sorted out and weighed using an electronic balance with a capacity of $300 \mathrm{~g}$ and an accuracy of $0.01 \mathrm{~g}$. Shells were washed with tap water to remove any remaining albumen and then dried at room temperature for 24 hours. They were individually weighed and their thickness measured with the same caliper at three levels: at the narrow end, the middle and the wide end. From the weighing and measurements of the external and internal characteristics, the following calculations were made:

$$
\text { Albumen weight }=\mathrm{We}-(\mathrm{Wy}+\mathrm{Ws})
$$

with Wy: yolk weight; We: whole egg weight and Ws: Cleaned and dried shell weight.

$$
\begin{aligned}
& \text { Proportion of egg components } \\
& =[(\text { Weight shell } / \text { yolk } / \text { Albumen }) /(\text { Egg Weight })] \times 100 \quad[11] .
\end{aligned}
$$

Edible matter content $=$ yolk percentage + Albumen percentage

$$
\text { Haugh Unit }(\mathrm{HU})=100 \log \left(\mathrm{H}+7.57-1.7 \mathrm{~W}^{0.37}\right)
$$

where H: Albumen height (mm); W: Egg weight (g); 7.57: Albumen height correction factor and 1.7: Egg weight correction factor.

\subsection{Dry Matter}

For the dry matter, a small quantity of egg yolk or egg albumen was placed in a capsule of known weight, and the whole was weighed before being placed in the oven at $105^{\circ} \mathrm{C}$. After about 120 minutes, it was removed, left to cool, weighed 
and then put back into the oven for about 15 minutes and the same procedure was followed until there was no variation in weight between 2 consecutive heating period. Dry matter percentage results from the following formula:

Percentage of dry matter

$=($ Dry matter weight $) /($ Fresh matter weight $) \times 100$

Fresh weight was obtained by subtracting the capsule weight plus sample from the capsule weight only. Similarly, dry matter weight results from the difference in weight between the capsule plus dried sample and the capsule.

\subsection{Statistical Analysis}

Data obtained were expressed as mean \pm standard deviation over the mean. A one-factor analysis of variance (ANOVA) was used. Where differences between means were significant, Duncan's test was used to separate them at $5 \%$ significance level. Microsoft Excel 2016 and IBM SPSS Statistics 25.0 software were used for the various analyses.

\section{Results}

\subsection{Laying Performances}

\subsubsection{Periodicity and Laying Rate According to Quail Phenotypes}

The effect of phenotype and breeding age on the egg-laying rate as a function of the laying period in quail is illustrated in Figure 1. In the white phenotype quails (Figure $1(\mathrm{a}))$, the laying rates obtained at one $(72.00 \% \pm 9.80 \%)$ and 10 months $(71.00 \% \pm 10.5 \%)$ were similar and significantly higher than the rate recorded at 6 months of laying. Between $4 \mathrm{pm}$ and $8 \mathrm{pm}$, quails of one and 10 months laid more eggs, while quails of one and 6 months had high laying rates between $8 \mathrm{pm}$ and $4 \mathrm{pm}$.

The spotted white phenotype quails (Figure 1(b)) at 1 month of laying age had a significantly higher laying rate $(93.33 \% \pm 9.43 \%)$ than those recorded in quails at 6 and 10 months of laying which were otherwise similar. White spotted quails of one month of breeding age laid more eggs between $4 \mathrm{pm}$ and $8 \mathrm{pm}$. The laying rate did not vary significantly with the age of the white spotted quail between $8 \mathrm{pm}$ and $4 \mathrm{pm}$.

In grey (Figure 1(c)) and brown (Figure 1(d)) phenotype quails, at 6 months oviposition rates $(78.75 \% \pm 6.29 \%$ and $74.00 \% \pm 12.44 \%$ respectively) were significantly higher than those obtained in quails at 1 and 10 months of laying which were otherwise similar. Between 4 pm - 8 pm, ten months old grey quails laid more eggs while six month old laid eggs between $8 \mathrm{pm}-4 \mathrm{pm}$. On the other hand, between $4 \mathrm{pm}-8 \mathrm{pm}$, brown quails had the highest laying rate in quails aged 6 months and between $8 \mathrm{pm}-4 \mathrm{pm}$ in quails aged between 6 and 10 months.

In all cases, regardless of the phenotype considered, egg-laying was more pronounced between $4 \mathrm{pm}$ and $8 \mathrm{pm}$ (Figure 1). 

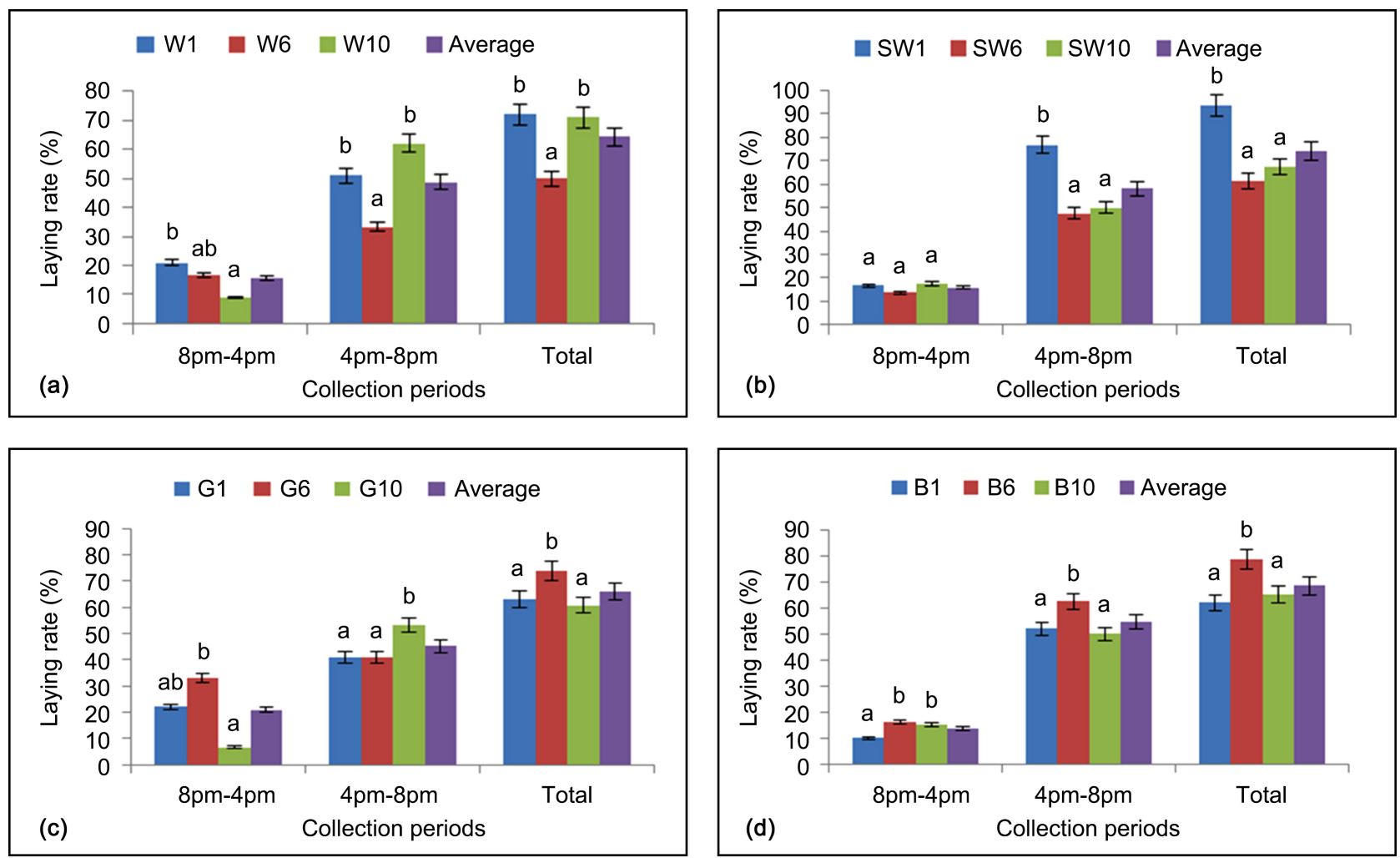

Figure 1. Egg laying rate as a function of phenotype, age and egg collecting period in white (a) spotted white (b) grey (c) and brown (d) quails. The numbers 1, 6 and 10 associated with the phenotypes mean respectively one, six and ten months of reproduction.

\subsubsection{Laying Rate in Quails as a Function of Periods Breeding Age and Collection Period}

Figure 2 illustrating the variation of the laying rate in quails as a function of breeding age shows that at one month (Figure 2(a)), spotted white phenotype quails showed a laying rate of $93.33 \% \pm 9.43 \%$ significantly higher than those obtained in white, grey and brown quails which were otherwise similar. Between $4 \mathrm{pm}$ and $8 \mathrm{pm}$, quails of the spotted white phenotype laid more eggs. For the 8 $\mathrm{pm}$ to $4 \mathrm{pm}$ time slot, brown and white phenotypes had the highest laying rates.

At six months of reproduction (Figure 2(b)), laying rates obtained in brown $(78.75 \% \pm 6.29 \%)$ and grey $(74.00 \% \pm 12.44 \%)$ phenotype quails were similar and significantly higher than those obtained in white and spotted white quails. Brown and grey quails laid more eggs between 4 and $8 \mathrm{pm}$ and 8 and $4 \mathrm{pm}$ respectively.

At ten months of reproduction (Figure $2(c))$, laying rates $(71.00 \% \pm 10.52 \%)$ recorded in white quails were significantly higher than those obtained in spotted white quails but similar to those obtained in brown and grey quails. Between 8 $\mathrm{pm}-4 \mathrm{pm}$ the spotted white phenotype and brown quails laid more eggs while between $4 \mathrm{pm}-8 \mathrm{pm}$ the laying rate did not vary significantly with feather colouration although the highest rate was noted with white phenotype quails.

In all cases, regardless of the age of the quail considered, laying was more abundant at the interval $4 \mathrm{pm}-8 \mathrm{pm}$ compared to $8 \mathrm{pm}-4 \mathrm{pm}$. 

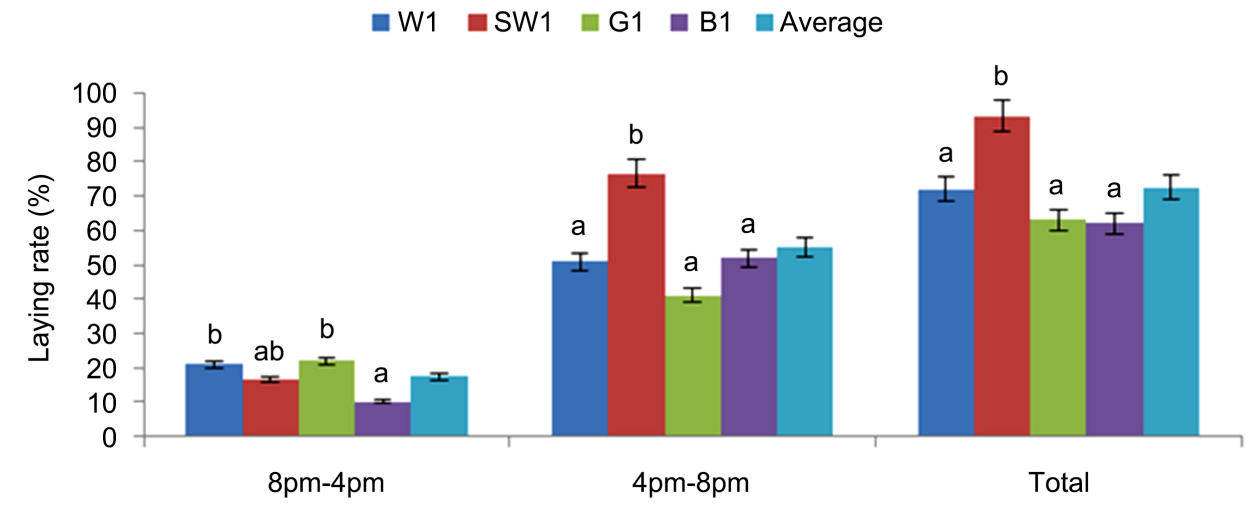

(a)

Collection periods
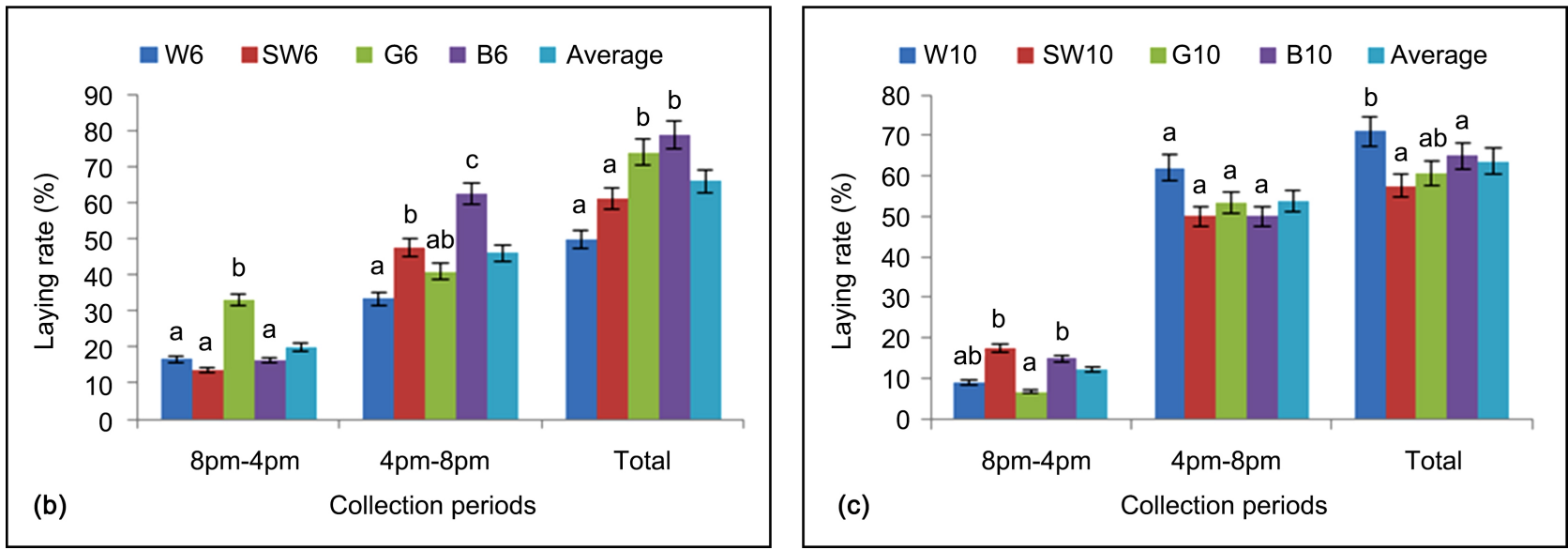

Figure 2. Laying rate as a function of age and egg collection period in quails of one month (a), six months (b) and ten months (c) of reproduction. The numbers 1, 6 and 10 associated with the phenotypes mean respectively one, six and ten months of reproduction.

\subsubsection{Laying Rate According to Age and Egg Collection Periods in Quails}

Regardless of the phenotype (Figure 3), quails at 1 month of breeding showed a significantly higher laying rate of $72.58 \% \pm 18.03 \%$ compared to those noted in quails at 6 and 10 months of breeding which were otherwise similar. Between 8 $\mathrm{pm}$ and $4 \mathrm{pm}$, the laying rate did not vary significantly with the breeding age of birds. However, between $4 \mathrm{pm}$ and $8 \mathrm{pm}$ quails of one and ten months of breeding age showed comparable laying rates but significantly higher than those of quails at 6 months of breeding age.

\subsubsection{Laying Rate According to Phenotype and Egg Collection Periods in Quails}

Quails of the spotted white phenotype showed a laying rate of $74.03 \% \pm 18.20 \%$ significantly higher than those obtained with the white, grey and brown phenotypes, which were otherwise comparable. Laying was highest between $8 \mathrm{pm}$ and $4 \mathrm{pm}$ in white quails and between $4 \mathrm{pm}$ and $8 \mathrm{pm}$ in grey quails. In all cases, regardless of the quail phenotype considered, laying was more pronounced between $4 \mathrm{pm}$ and $8 \mathrm{pm}$ compared to $8 \mathrm{pm}-4 \mathrm{pm}$ (Figure 4). 


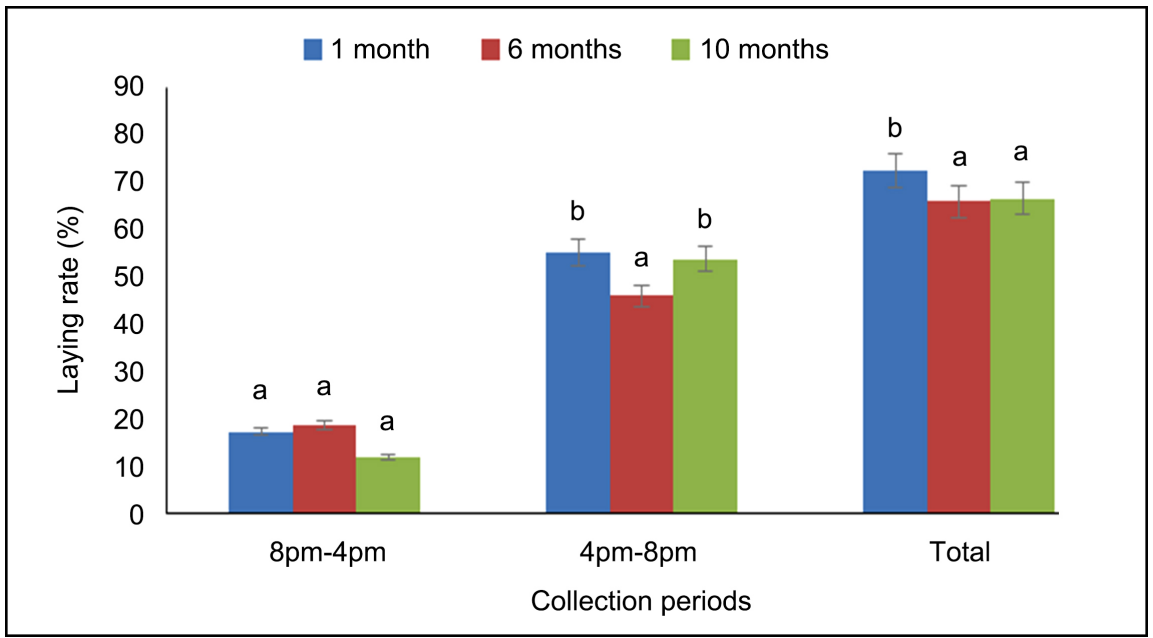

Figure 3. Laying rate as a function of age and egg collection periods in quails.

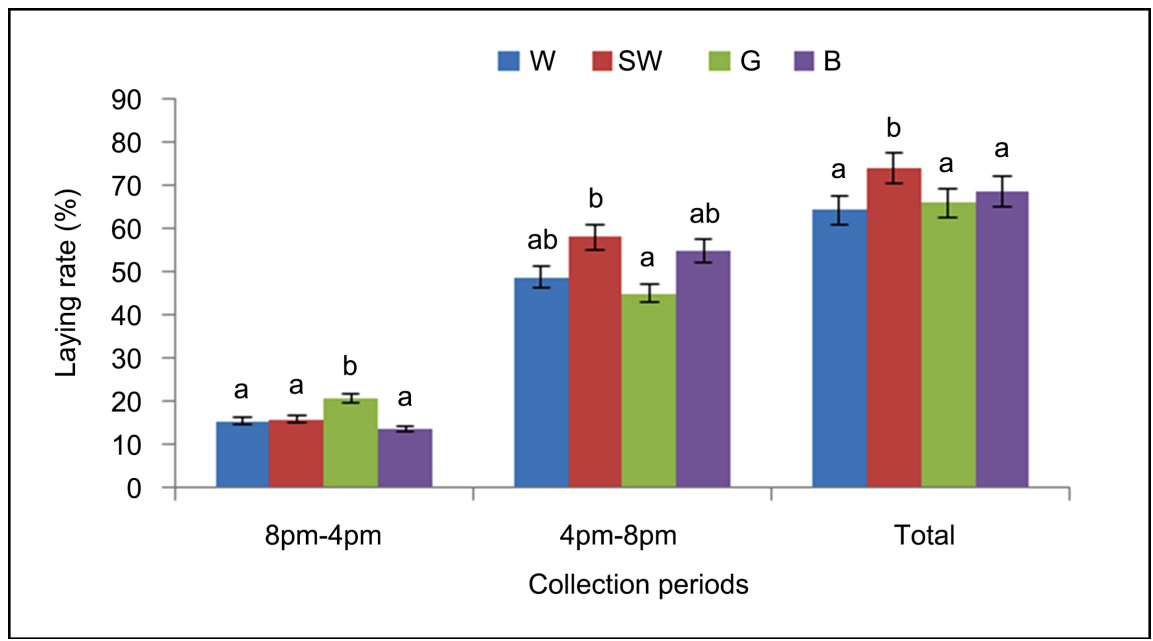

Figure 4. Laying rate according to phenotype and egg collection periods in quails. W: White; SW: Spotted White; G: Grey; B: Brown. periods.

\subsection{External and Internal Characteristics of Quail Eggs According to Phenotypes}

Weight, height, large diameter and feed efficiency for eggs were not significantly affected by quail phenotype (Table 2). In all cases, the eggs of white quails had a volume of $12.60 \pm 0.77 \mathrm{~mL}$ significantly higher than those of spotted white and brown quails, but similar to those of grey quails. On the other hand, brown, white spotted and grey quails had similar egg volumes.

The eggs of spotted white quails had a white diameter of $20.77 \pm 3.61 \mathrm{~mm}$ comparable to that of grey quails but significantly higher than the others. Yolk diameter of white quails was significantly smaller than those of the other phenotypes which were otherwise comparable. The height of the albumen of $4.25 \pm$ $0.72 \mathrm{~mm}$ and the haugh unit of $88.27 \pm 3.90$ of grey quail eggs were significantly higher but similar to those recorded with the brown phenotypes. On the other hand, yolk height did not show any significant variation with phenotypes. 
Table 2. External and internal characteristics of quail eggs according to their phenotype.

\begin{tabular}{|c|c|c|c|c|c|}
\hline \multirow{2}{*}{ Characteristics } & \multicolumn{5}{|c|}{ Phenotypes } \\
\hline & White & Spotted White & Grey & Brown & Mean \\
\hline Weight (g) & $10.54 \pm 0.45^{\mathrm{a}}$ & $10.40 \pm 0.61^{\mathrm{a}}$ & $10.29 \pm 0.50^{\mathrm{a}}$ & $10.46 \pm 0.38^{\mathrm{a}}$ & $10.42 \pm 0.48$ \\
\hline Height (mm) & $31.86 \pm 0.63^{\mathrm{a}}$ & $31.73 \pm 0.86^{\mathrm{a}}$ & $31.74 \pm 0.84^{\mathrm{a}}$ & $31.52 \pm 0.61^{\mathrm{a}}$ & $31.71 \pm 0.72$ \\
\hline Diameter $(\mathrm{mm})$ & $24.92 \pm 0.88^{\mathrm{a}}$ & $24.71 \pm 0.32^{\mathrm{a}}$ & $24.57 \pm 0.39^{a}$ & $24.81 \pm 0.25^{\mathrm{a}}$ & $24.75 \pm 0.53$ \\
\hline Shape index & $0.78 \pm 0.02^{\mathrm{a}}$ & $0.78 \pm 0.02^{\mathrm{a}}$ & $0.78 \pm 0.02^{\mathrm{a}}$ & $0.79 \pm 0.02^{\mathrm{a}}$ & $0.78 \pm 0.02$ \\
\hline Volume (ml) & $12.60 \pm 0.77^{\mathrm{b}}$ & $11.60 \pm 1.5^{\mathrm{ab}}$ & $10.90 \pm 1.2^{\mathrm{a}}$ & $11.25 \pm 1.6^{\mathrm{a}}$ & $11.59 \pm 1.44$ \\
\hline \multicolumn{6}{|l|}{ Internal characteristics } \\
\hline Albumen Diameter (mm) & $16.16 \pm 3.48^{\mathrm{a}}$ & $20.77 \pm 3.6^{\mathrm{b}}$ & $17.84 \pm 3.0^{\mathrm{ab}}$ & $17.05 \pm 3.8^{\mathrm{a}}$ & $17.95 \pm 3.80$ \\
\hline Albumen height (mm) & $3.02 \pm 0.65^{\mathrm{a}}$ & $3.25 \pm 1.05^{\mathrm{ab}}$ & $4.25 \pm 0.72^{\mathrm{c}}$ & $3.88 \pm 0.74^{\mathrm{bc}}$ & $3.60 \pm 0.92$ \\
\hline Yolk diameter (mm) & $22.50 \pm 1.83^{\mathrm{a}}$ & $24.58 \pm 1.4^{\mathrm{b}}$ & $25.47 \pm 0.9^{\mathrm{b}}$ & $25.24 \pm 2.1^{\mathrm{b}}$ & $24.45 \pm 1.96$ \\
\hline Yolk Height (mm) & $10.20 \pm 1.83^{\mathrm{a}}$ & $10.19 \pm 1.4^{\mathrm{a}}$ & $10.45 \pm 0.9^{\mathrm{a}}$ & $10.12 \pm 2.1^{\mathrm{a}}$ & $10.24 \pm 1.96$ \\
\hline Haugh Unit (\%) & $80.50 \pm 5.09^{\mathrm{a}}$ & $81.95 \pm 6.9^{\mathrm{ab}}$ & $88.27 \pm 3.9^{c}$ & $86.17 \pm 4.6^{\mathrm{bc}}$ & $84.22 \pm 5.99$ \\
\hline \multicolumn{6}{|c|}{ Weight and percentage of egg components } \\
\hline Yolk weight (g) & $3.39 \pm 0.56^{\mathrm{a}}$ & $3.48 \pm 0.35^{\mathrm{ab}}$ & $3.70 \pm 0.29^{\mathrm{ab}}$ & $3.89 \pm 0.51^{\mathrm{b}}$ & $3.66 \pm 0.47$ \\
\hline Shell weight (g) & $0.84 \pm 0.03^{\mathrm{bc}}$ & $0.88 \pm 0.05^{\mathrm{c}}$ & $0.76 \pm 0.06^{\mathrm{a}}$ & $0.80 \pm 0.06^{\mathrm{ab}}$ & $0.82 \pm 0.07$ \\
\hline Albumen weight (g) & $7.09 \pm 0.68^{\mathrm{b}}$ & $6.76 \pm 0.5^{\mathrm{b}}$ & $6.78 \pm 0.40^{\mathrm{b}}$ & $5.68 \pm 2.07^{\mathrm{a}}$ & $6.58 \pm 1.22$ \\
\hline Yolk proportion (g) & $29.88 \pm 3.51^{\mathrm{a}}$ & $31.26 \pm 1.5^{\mathrm{ab}}$ & $32.89 \pm 1.2^{\mathrm{bc}}$ & $35.03 \pm 3.4^{\mathrm{c}}$ & $32.27 \pm 3.20$ \\
\hline Albumen proportion $(\mathrm{g})$ & $62.64 \pm 3.45^{\mathrm{b}}$ & $60.86 \pm 1.6^{\mathrm{b}}$ & $60.38 \pm 1.1^{\mathrm{b}}$ & $57.79 \pm 3.4^{\mathrm{a}}$ & $60.41 \pm 3.09$ \\
\hline \multicolumn{6}{|l|}{ Shell characteristics } \\
\hline Shell proportion $(\mathrm{mm})$ & $7.47 \pm 0.51^{\mathrm{b}}$ & $7.92 \pm 0.46^{\mathrm{c}}$ & $6.73 \pm 0.45^{\mathrm{a}}$ & $7.18 \pm 0.40^{\mathrm{b}}$ & $7.33 \pm 0.62$ \\
\hline Large end shell thickness (mm) & $0.29 \pm 0.06^{\mathrm{b}}$ & $0.21 \pm 0.02^{\mathrm{a}}$ & $0.23 \pm 0.06^{\mathrm{a}}$ & $0.22 \pm 0.03^{\mathrm{a}}$ & $0.24 \pm 0.05$ \\
\hline Medium end shell thickness (mm) & $0.17 \pm 0.01^{\mathrm{a}}$ & $0.20 \pm 0.03^{\mathrm{b}}$ & $0.21 \pm 0.03^{\mathrm{b}}$ & $0.20 \pm 0.02^{\mathrm{b}}$ & $0.19 \pm 0.03$ \\
\hline Small end shell thickness (mm) & $0.26 \pm 0.04^{\mathrm{b}}$ & $0.21 \pm 0.01^{\mathrm{a}}$ & $0.22 \pm 0.04^{\mathrm{a}}$ & $0.24 \pm 0.05^{\mathrm{ab}}$ & $0.23 \pm 0.04$ \\
\hline Average shell thickness (mm) & $0.24 \pm 0.02^{\mathrm{b}}$ & $0.21 \pm 0.01^{\mathrm{a}}$ & $0.22 \pm 0.04^{\mathrm{ab}}$ & $0.22 \pm 0.02^{\mathrm{ab}}$ & $0.22 \pm 0.03$ \\
\hline \multicolumn{6}{|l|}{ Water and edible matter content } \\
\hline Albumen dry matter content (\%) & $10.15 \pm 0.24^{\mathrm{a}}$ & $10.22 \pm 0.17^{\mathrm{a}}$ & $10.18 \pm 0.41^{\mathrm{a}}$ & $9.85 \pm 0.18^{\mathrm{a}}$ & $10.10 \pm 0.28$ \\
\hline Yolk dry matter content (\%) & $49.07 \pm 0.23^{\mathrm{a}}$ & $50.24 \pm 0.57^{\mathrm{ab}}$ & $50.51 \pm 0.94^{\mathrm{ab}}$ & $50.76 \pm 1.11^{\mathrm{b}}$ & $50.15 \pm 0.95$ \\
\hline Albumen moisture content (\%) & $89.85 \pm 0.24^{\mathrm{a}}$ & $89.77 \pm 0.17^{\mathrm{a}}$ & $89.82 \pm 0.41^{\mathrm{a}}$ & $90.15 \pm 0.18^{\mathrm{a}}$ & $89.90 \pm 0.28$ \\
\hline Yolk moisture content (\%) & $50.92 \pm 0.23^{\mathrm{b}}$ & $49.76 \pm 0.57^{\mathrm{ab}}$ & $49.48 \pm 0.94^{\mathrm{ab}}$ & $49.24 \pm 1.11^{\mathrm{a}}$ & $49.85 \pm 1.11$ \\
\hline Edible matter content (\%) & $92.52 \pm 0.51^{\mathrm{b}}$ & $92.08 \pm 0.46^{\mathrm{a}}$ & $93.27 \pm 0.45^{\mathrm{c}}$ & $92.81 \pm 0.40^{\mathrm{b}}$ & $92.67 \pm 0.62$ \\
\hline
\end{tabular}

${ }^{\mathrm{a}},{ }^{\mathrm{b}}$ and ${ }^{\mathrm{c}}$ on the same line. the values affected by the same letter are not significantly different $(\mathrm{P}>0.05)$. 
The highest yolk weight was obtained in quails with the brown phenotype and was similar to that recorded in grey and spotted white phenotypes. White spotted quail eggs had shell weights that were similar to those of white quail eggs but significantly higher than those of grey and brown quails. It was also observed that the weight and proportions of egg albumen obtained from brown phenotype quails were significantly lower than those of other phenotypes that were otherwise similar. However, the percentage of yolk obtained from quails with brown phenotype $35.03 \% \pm 3.42 \%$ was similar to that recorded in grey quails and significantly higher than those of other phenotypes which recorded similar proportions.

Quail eggs with the spotted white phenotypes had significantly a higher proportion of shell $(7.92 \% \pm 0.46 \%)$ compared to those with other phenotypes. The highest value of shell thickness at the large end $(0.29 \pm 0.06)$ was obtained in the eggs of white quails, which, however, presented the lowest value at the medium end $(0.17 \pm 0.01 \mathrm{~mm})$. The greatest shell thickness $(0.26 \pm 0.04)$ was obtained on eggs of white quails, and was similar to the one recorded from brown quails. Similarly, the average of the smallest shell thickness recorded with spotted white quail $(0.21 \pm 0.01)$ was similar to the one recorded with grey and brown quails.

The percentage of dry matter in the egg albumen does not significantly change with the phenotype. However, the eggs of white quails had the lowest percentage of yolk dry matter $(49.07 \% \pm 0.23 \%)$ and the highest moisture content $(50.92 \pm$ 0.23) similar to those of spotted white and grey quails respectively. The edible matter percentage of quail eggs of grey phenotype $(93.27 \% \pm 0.45 \%)$ was significantly higher than the one recorded in the white, spotted white and brown phenotypes.

The proportions of the shells of spotted white and grey quail eggs were the highest and lowest respectively. The shell thickness of white quail eggshells was significantly higher at the large end but significantly lower at the middle part of the egg. Globally, the average egg thickness was higher for quails with white phenotype and lower for quails with spotted white phenotype.

The dry matter and moisture content of the albumen were similar regardless the phenotype. Brown phenotype quails had significantly a higher dry matter content in the egg yolk than quails with white phenotype while being similar to spotted white and grey phenotype quails.

\section{Discussion}

Our results revealed that laying rate is higher between $4 \mathrm{pm}$ and $8 \mathrm{pm}$ whatever the age of birds and the genetic type considered. These results are in agreement with the observations made by Sauveur [12] who states that unlike hens whose laying is done in the morning, oviposition in quails is generally done in the afternoon between $4 \mathrm{pm}$ and $8 \mathrm{pm}$ with little oviposition in the morning.

Quails of the spotted white phenotype had the highest laying rate compared to other phenotypes. This could be attributed to the breed of the birds being more 
prone to lay eggs than the other phenotypes. These results do not agree with the findings of Jessy et al. (2016) who found that laying rate is higher in grey quails (86.65\%) compared to brown $(76.0 \%)$ and white $(67.16 \%)$ quails. The values found in our study are lower than those reported by these authors and could be explained by genetic and environmental factors.

In brown and grey quails, laying rates were higher at six months of breeding ( $78.75 \%$ and $74 \%$ respectively). These results are similar to those obtained by Jessy et al. (2016) who indicate that in the 8th week, laying rate of brown quails $(58.9 \%)$ increases with animal age up to $89 \%$ at around the 12 th week and drops to $76 \%$ by the 20 th week. Hantanirina et al. [13] also showed that laying rates vary from $78 \%$ to $43 \%$ between the 6 th and the 32 nd week of life of grey quails. In white quails, the highest laying rates $(72 \%$ and $71 \%)$ were respectively recorded at 1 and 10 months of breeding. Hantanirina et al. [13] obtained similar results at 14 weeks of age in white and grey quails. In spotted white quails, the highest laying rate was recorded in quails that had been laying for 1 month (93.34\%). These results are similar to findings of Hantanirina et al. [13] and Jessy et al. (2016) which respectively show a laying rate between $(80 \%-90 \%)$ and $(60 \%-99 \%)$ at the 4 th week of breeding in all quail strains. This variation of results with other authors may be due to the genetic types of quails as well as environmental and managerial factors.

The significantly higher laying rate $(72 \%)$ was recorded with birds of onemonth breeding age. These results are close to those obtained by Hantanirina et al. [13] who found that the laying performance at the beginning of the laying period was between $15.12 \%$ and $29 \%$ and reached $80 \%-90 \%$ at one month of laying. Overall, more or less significant differences were found between results of the authors with regard to the overall quality of laying. This is influenced by a combination of both intrinsic (strain, age, body weight) and extrinsic factors (sex ratio, diet, temperature, photoperiod etc.). The fact that the laying rates obtained at one $(72.00 \% \pm 9.80 \%)$ and 10 months $(71.00 \% \pm 10.5 \%)$ were similar and significantly higher than the rate recorded at 6 months of laying could be explained by some fluctuation of the oviposition during the laying carrier of hen. Indeed, laying is characterized by some cyclicity that leads to some reduction of the egg production inside a flock [12].

Average egg weight was $10.42 \mathrm{~g}$. Hrncar et al. [9] found higher values (11.48 g and $13.06 \mathrm{~g}$ ) in Japanese quails for laying and meat respectively. The average shape index of $78.73 \%$ obtained is close to the $78.2 \%$ reported by Ouaffai et al. [7]. According to Nedeljka [14], shape index between $70 \%$ and $77 \%$ can be estimated as optimal in poultry and hens precisely. It should be however noted that younger laying birds give higher shape indexes and more rounded eggs; furthermore, the high values of the shape index obtained in our trial could be due to the poultry species used. White phenotype quail eggs had a volume of 12.60 $\mathrm{ml}$, significantly higher than those of other phenotypes. This difference can be attributed to the higher weight, diameter and height of eggs of the same pheno- 
type. These results are similar to those recorded by Kanagaraju et al. [15] who reported egg volumes between 10.36 and $11.64 \mathrm{ml}$ depending on the phenotype.

Spotted white quail eggs had the largest egg albumen diameter $(20.77 \mathrm{~mm})$ compared to other phenotypes. White quail eggs, on the other hand, recorded the lowest yolk diameter value $(22.50 \mathrm{~mm})$. These results do not agree with those of Jessy et al. [16]; Begum et al. [17] who reported higher values (between 32 and $37 \mathrm{~mm}$ ) that plumage colouring does not significantly affect egg albumen diameter in quails Şeker et al. [18], in a study on the effect of storage time on egg quality in laying hens, found that the diameter increased with storage time. These observations were also confirmed by Djitie et al. [19] by evaluating the effect of storage time on the physico-chemical characteristics of eggs from backyard systems. The genetic type and storage time of the eggs are the main factors that can justify the low values of the albumen diameter obtained in the present study.

Albumen height and eggshell thickness also varied significantly with the quail phenotype, corroborating the results obtained by Rasol et al. [20] and Kanagaraju et al. [15]. However, Jessy et al. [16] reported that feather coloration did not significantly affect height or thickness of Japanese quail egg constituents.

The overall yolk proportion was $32.27 \%$ with the lowest value reported in white quails and the highest in brown quails. This could be due to the fact that the brown quail egg yolk was heavier. These results are similar to those reported by Kanagaraju et al. [15]. Hrncar et al. [9] also reported similar values in laying $(32.43 \%)$ and meat (35.84\%) quails. With an average of $60.41 \%$, the lowest proportion of egg albumen (57.79\%) was obtained in brown quail eggs. Kanagaraju et al. [15] reported higher values for brown (62.67\%), white (65.19\%) and golden (62.50) plumage quails. Variations in the proportion of albumen egg from one quail phenotype to another could be explained by a variability in the process of setting of the different egg constituents according to the phenotype. The proportion of eggshell overall was $7.33 \%$ with the lowest value $(6.73 \%)$ recorded in grey quail eggs and the highest (7.93\%) in spotted white quail eggs. These results are not consistent with those of Begum et al. [17] who found higher (9\% - 10\%) and otherwise comparable values in white, grey, fawn, black and tuxedo quails.

Haugh's index was higher with grey quail eggs (88.17\%). This might be an indication that grey quail eggs age slower than those of other phenotypes. Similar results were reported by Kanagaraju et al. [15] in brown (87.68) and white (84.78) quails. Other authors [9] [21] rather noted that Haugh's index did not vary significantly with genetic type. This difference in results with other authors could be explained by the egg storage duration and the age of the birds.

\section{Conclusions}

At the end of our study on the effect of quail phenotype and age on the laying rate and egg characteristics, it was found that:

- laying is concentrated between $4 \mathrm{pm}-8 \mathrm{pm}$ on all phenotypes. Although the 
laying rate varies from one phenotype to another with age, white spotted quails showed significantly higher laying rates compared to other phenotypes throughout the survey;

- Except for egg volume, which was higher in white quails, external egg characteristics were generally similar between all quail phenotypes.

- The white spotted quails' eggshells were significantly thicker than those of the other phenotypes. Grey quails had higher Haugh's index eggs and a proportion of edible matter.

Considering these results, it can be concluded that although grey quails had high proportions of edible matter, white spotted quails are more suitable for reproduction since they have the best egg laying performance and better shell quality.

\section{Conflicts of Interest}

The authors declare no conflicts of interest regarding the publication of this paper.

\section{References}

[1] Dahloum, L. (2017) Phenotypical Characterisation of the Local Hen (Gallus gallus) in North-Western Algeria. Major Genes and Thermo-Tolerance. Doctoral Thesis in Sciences, University of Mostaganem, Algeria, $140 \mathrm{p}$.

[2] FAO (2009) How to Feed the World in 2050. High-Level Expert Forum, Rome, 12-13 October, $2 \mathrm{p}$.

[3] Bensalah, A. (2016) Effets de quelques formules alimentaires sur les performances zootechniques et le profil Biochimique de la caille japonaise. Mémoire de Magistère en sciences vétérinaire. Département de Productions Animales, Université des Frères Mentouri Constantine, Constantine, Algeria, $131 \mathrm{p}$.

[4] Djitie, K.F., Kana, J.R., Ngoula, F., Nana, N.F.C. and Teguia, A. (2015) Effect of Crude Protein Level on Growth and Carcass in Quail (Coturnix sp.) in the Finishing Phase in the Cameroon Highlands. Livestock Research for Rural Development, 27 1-10. http://www.lrrd.org/lrrd27/8/koua27155.htm

[5] Kayang, B.B., Miho, V.F., Muyama, I., Miwa, M., Leroux, S., Katia, F., Monvoisin, J.L., Pitel, F., Vignol, M., Mouihayrat, C., Beaumont, C., Ito, S.I., Minvielle, F. and Vaginal, A. (2006) Integrated Maps in Quail (Coturnix coturnix japonica) Confirm the High Degree of Synteny Conservation with Chicken (Gallus gallus) Despite 35 Million Years of Divergence. BMC Genomics, 7, 10-51.

https://doi.org/10.1186/1471-2164-7-101

[6] Berrama, Z., Mefti, H., Kaidi, R. and Souames, S. (2011) Zootechnical Characterization and Genetic Parameters of the Growth Performances of the Japanese Quail Coturnix Japonica Reared in Algeria. Livestock Research for Rural Development, 23, 1-14. http://www.lrrd.org/lrrd23/1/berr23003.htm

[7] Ouaffai, A., Dahloum, L., Fassih, A., Milagh, M. and Halbouche, M. (2018) Growth Performances, Egg Laying and Egg Quality in Japanese Quails (Coturnix coturnix japonica). Archivos de Zootecnia, 67, 168-176. https://doi.org/10.21071/az.v67i258.3651

[8] Alkan, S., Karabag, K., Galic, A., Karsli, T., Balcioglu, M.S. (2010) Effect of Selection for Body Weight and Egg Production on Egg Quality Traits in Japanese Quails 
(Coturnix coturnix japonica) of Different Lines and Relationships between These Traits. Kafkas Universitesi Veteriner Fakuiltesi Dergisi, 16, 239-244.

[9] Hrncar, C., Hanusova, E., Hanus, A. and Bujko, J. (2014) Effect of Genotype on Egg Quality Characteristics of Japanese Quail (Coturnix japonica). National Agricultural and Food Center. Research Institute for Animal Production Nitra. Slovak Journal of Animal Science, 47, 6-11.

[10] Katchouang, A.S.N., Djitie, F.K., Meutchieye, F., Kana, J.R. and Teguia, A. (2015) Characteristics of Quail (Coturnix sp) Farms in Mfoundi Department, Centre Region, Cameroon. Livestock Research for Rural Development, 27, Article 77. http://www.lrrd.org/lrrd27/4/katc27077.html

[11] El-Deen, M.B., Kosba, M. and Soliman, A. (2009) Studies of Some Performance and Blood Constituents Traits in Japanese Quail, Egyptian Poultry Science Journal, 29, 1187-1208.

[12] Sauveur, B. (1988) Reproduction des volailles et production d'œufs. INRA Editions, Paris, $449 \mathrm{p}$.

[13] Hantanirina, H.I., Rabearimisa, R.N. and Rakotozandriny, J.N. (2013) Quail Domestication in Madagascar: Case of the Japanese Quail “Coturnix japonica” (Termminck \& Schlegel, 1849). Essa-Forets, org, 32, 24-33.

[14] Nedeljka Nikolova D.K. (2006) Forming Egg Shape Index as Influenced by Ambient Tempertaure and Age of Hens. Biotechnology in Animal Husbandry, 22, 119-125. https://doi.org/10.2298/BAH0602119N

[15] Kanagaraju, P., Babu, M., Asha, R.R., Richard, C.R., Rathnapraba, S. and Omprakash, A.V. (2013) A Study of Egg Quality Characteristics of Different Varieties of Japanese Quail. Institute of Poultry production and Management, 90, 70-72.

[16] Jessy, B., Panigrahi, B., Panda, N., Pradhan, C.R., Mallik, B.K., Majhi, B. and Rout, S.S. (2016) Body Weight, Egg Production, and Egg Quality Traits of Gray, Brown, and White Varieties of Japanese Quail (Coturnix coturnix japonica) in Coastal Climatic Condition of Odisha. Veterinary Word, 9, 832-836.

https://doi.org/10.14202/vetworld.2016.832-836

[17] Begum, S., Yeasmin, M.N., Morduzzaman, M., Howlider, M.A.R. and Hossain, M.S. (2016) Study on Egg Quality of Seven Different Plumage Color Mutant Varieties of Japanese Quail Isolated at BAU. International Journal of Emerging Technologies in Research, 4, 77-80.

[18] Seker, I., Kul, S., Bayraktar, M. and Yildirim, O. (2005) Effect of Layer Age on Some Egg Quality Characteristics and Egg Production in Japanese Quail (Coturnix coturnix japonica). Journal of the Faculty of Veterinary Medicine, University of Ankara, 31, 129-138.

[19] Djitie, K.F., Usturoi, M.G., Radu-Rusu, R.M., Aida, A. and Simiz, E. (2020) Effect of Storage Time at Low Temperature on Physico-Chemical Characteristics of Eggs from Hens Kept in Backyard System in the City of Iasi in Romania. Scientific Papers: Animal Science \& Biotechnologies. 2020, 53, 229-238.

[20] Al-Kafajy, F.R., Al-Shuhaib, M.B.S., Al-Jashami G.S. and Al-Thuwaini, T.M. (2018) Comparison of Three Lines of Japanese Quails Revealed a Remarkable Role of Plumage Color in the Productivity Performance Determination. The Journal of World's Poultry Research, 8, 111-119.

[21] Chimezie, V.O., Fayeye, T.R., Ayorinde, K.L. and Adebunmi, A. (2017) Phenotypic Correlations between Egg Weight and Some Egg Quality Traits in Three Varieties of Japanese Quail (Coturnix coturnix japonica). Agrosearch, 17, 44-53. https://doi.org/10.4314/agrosh.v17i1.4 